\title{
A new high-frequency allele of the BM2113 locus in the Yunnan mithun population
}

\author{
K.-X. Qu ${ }^{1,2 *}$, Z.-X. He ${ }^{3 *}$, R.-J. Hao', J.-C. Zhang ${ }^{3}$, B.-Z. Huang ${ }^{3}$, \\ L.-S. Zan ${ }^{1,4}$ and Y.-P. Zhang ${ }^{2}$ \\ ${ }^{1}$ College of Animal Science and Technology, Northwest A\&F University, \\ Yangling, Shaanxi, China \\ ${ }^{2}$ State Key Laboratory of Genetic Resources and Evolution \& Yunnan Key \\ Laboratory of Molecular Biology of Domestic Animals, \\ Kunming Institute of Zoology, The Chinese Academy of Sciences, \\ Kunming, Yunnan, China \\ ${ }^{3}$ Yunnan Academy of Grassland and Animal Science, Kunming, Yunnan, China \\ ${ }^{4}$ National Beef Cattle Improvement Center of China, Yangling, Shaanxi, China \\ *These authors contributed equally to this study. \\ Corresponding authors: L.-S. Zan / Y.-P. Zhang \\ E-mail: zanlinsen@163.com / zhangyp@mail.kiz.ac.cn
}

Genet. Mol. Res. 13 (1): 2155-2159 (2014)

Received May 24, 2013

Accepted November 28, 2013

Published March 24, 2014

DOI http://dx.doi.org/10.4238/2014.March.24.23

\begin{abstract}
The BM2113 locus was amplified in Yunnan mithun (Bos frontalis) from the southwest mountains of China. It showed a high degree of polymorphism with a total of 12 alleles. The 121-bp polymorphic allele of the BM2113 locus that accounted for $37.1 \%$ of homozygotes was the predominant allele with a frequency of $58.57 \%$, identified as mithunspecific for Bos species in Yunnan mithun. The polymorphism information content value was high with a mean of 0.6170 , the expected and observed heterozygosity was moderate with values of 0.6427 and 0.6000 , respectively, and the BM2113 locus was under Hardy-Weinberg equilibrium ( $\mathrm{P}=$ 0.2897 ) in the Yunnan mithun population. This study elucidated the genetic diversity, multi-origin, specific alleles, and characterization of mithun.
\end{abstract}

Key words: Yunnan mithun (Bos frontalis); BM2113; Polymorphism 


\section{INTRODUCTION}

Mithun (Bos frontalis), which is also known as gayal and Dulong cattle by the Dulong tribe in Yunnan, China, is a species of Bos that is under a semi-management and rare status in the forests of Southeast Asia. In Yunnan, Dulong cattle is native to the Nujiang River and Gaoligongshan Mountains. It has a small population size, about 3000, with phenotypes that are similar to those of the Asian gaur. For example, it has a distinct spinous dorsal ridge, wide forehead, short-wide ears, and dark brown coat with white stockings (Lekagul and McNeely, 1977, 1988; Kakampuy et al., 2007; He et al., 2009). However, Yunnan mithun underwent introgression and genetic erosion from domestic cattle (Bos taurus and Bos indicus) based on microsatellite loci and mitochondrial DNA markers with multi-origin (Gou et al., 2010; Qu et al., 2012).

The BM2113 locus was designated and deposited in GenBank (accession No. M97162; Sunden et al., 1993); it exhibits Mendelian inheritance, contains an (AC/GT) ${ }_{20}$ microsatellite, revealing a high degree of polymorphism in bovid species, and is located on chromosome 2. To shed light on the polymorphism of the BM2113 locus in the Yunnan mithun population, we scanned it to provide information to facilitate genetic diversity, genetic components, and phylogeny studies of mithun.

\section{MATERIAL AND METHODS}

\section{Animals}

Thirty-five mithuns (Bos frontalis, 6 males and 29 females) were from Phoenix Mountains, Jiumudang Farm of Yunnan Province, China, including one additional sample of frozen semen (He et al., 2009).

\section{Polymerase chain reaction (PCR) and genotyping}

Total DNA was extracted according to a previous study (Qu et al., 2006). The following primers were used: forward primer, 5'FAM-GCTGCCTTCTACCAAATACCC-3'; and reverse primer, 5'-CTTCCTGAGAGAAGCAACACC-3' (Sunden et al., 1993). PCR was performed in a $10-\mu \mathrm{L}$ volume containing $20-50 \mathrm{ng} / \mu \mathrm{L}$ total DNA, $1.0 \mathrm{pmol}$ each primer, $0.125 \mathrm{U}$ Taq polymerase, $0.1 \mathrm{mM}$ each dNTP, $1.0 \mathrm{mM} \mathrm{MgCl}_{2}$, and $1.0 \mu \mathrm{L} 10 \mathrm{X}$ PCR Buffer. The PCR procedure involved initial denaturation at $94^{\circ} \mathrm{C}$ for $4 \mathrm{~min} ; 25$ cycles of $30 \mathrm{~s}$ at $94^{\circ} \mathrm{C}, 40 \mathrm{~s}$ at $54^{\circ} \mathrm{C}$, and $30 \mathrm{~s}$ at $72^{\circ} \mathrm{C}$; and a final extension at $72^{\circ} \mathrm{C}$ for $10 \mathrm{~min}$. PCR products were diluted and mixed with LIZ 500 size standards according to the procedure for microsatellite markers and were electrophoresed on an ABI PRISM 3730 DNA analyzer (ABI, USA) (Qu et al., 2006, 2012). Allele scoring was performed using the GENEMAPPER 3.0 software.

\section{Data extraction and statistical analysis}

Genotyping data of mithun (Bos frontalis) was extracted from the GENEMAPPER software 3.0. Genotypes of the locus were collected in an Excel file and then converted to a computable file format through Excel Microsatellite Toolkit Version 3.1 (http://animalgenom- 
ics.ucd.ie/sdepark/ms-toolkit/index.php). Allelic frequencies, mean number of alleles per locus, and exact test for Hardy-Weinberg $(\mathrm{H}-\mathrm{W})$ equilibrium were calculated using the Genepop computer package (Version 3.4; Raymond and Rousset, 1995). The polymorphism information content (PIC) for loci was calculated according to Botstein et al. (1980).

\section{RESULTS AND DISCUSSION}

The genotypes of 35 mithuns (Bos frontalis) from Yunnan Province, China, showed high polymorphism and a total of 12 alleles as shown in Figure 1. The allele 121 bp was the predominant allele with a value of $58.57 \%$ (Figures 1 and 2), and it was identified as mithunspecific among the bovid species because $37.1 \%$ were homozygous for the allele $121 \mathrm{bp}$. Liao et al. defined it as specific-allele $120 \mathrm{bp}(63.2 \%)$ in mithun from Yunnan Province (Liao et al., 2008; Zhang et al., 2008); however, there were distinct discrepancies between this report and that from Tian et al. (2011), who used silver staining. Allele $121 \mathrm{bp}$ was absent in European cattle breeds (MacHugh et al., 1997), Brazilian Gir (Bicalho et al., 2006), Vietnamese cattle and wild gaur (Nguyen et al., 2007), Indian Kangayam cattle (Karthickeyan et al., 2009), Colombia Brahman cattle (Novoa and Usaquén, 2010), Uruguayan Creole cattle (Armstrong et al., 2013), Mongolian and Russian yak (Xuebin et al., 2005), Swiss yak (Nguyen et al., 2005), and Chinese yak (Liao et al., 2008; Zhang et al., 2008). No detailed data were shown for other bovid species in the previous studies on the BM2113 locus (Kantanen et al., 2000; Ritz et al., 2000; Kim et al., 2002; Zhang et al., 2007a,b, 2011; Mao et al., 2008; Wang et al., 2008; Rivière-Dobigny et al., 2009; Li and Kantanen, 2010; Azam et al., 2012). Herein, the PIC value was high and had a mean of 0.6170 , the expected and observed heterozygosity was moderate with values of 0.6427 and 0.6000 , respectively, and the BM2113 locus was in H-W equilibrium $(\mathrm{P}=0.2897)$ in the Yunnan mithun population. This study revealed the genetic diversity, multi-origin, specific alleles, and characterization of mithun.

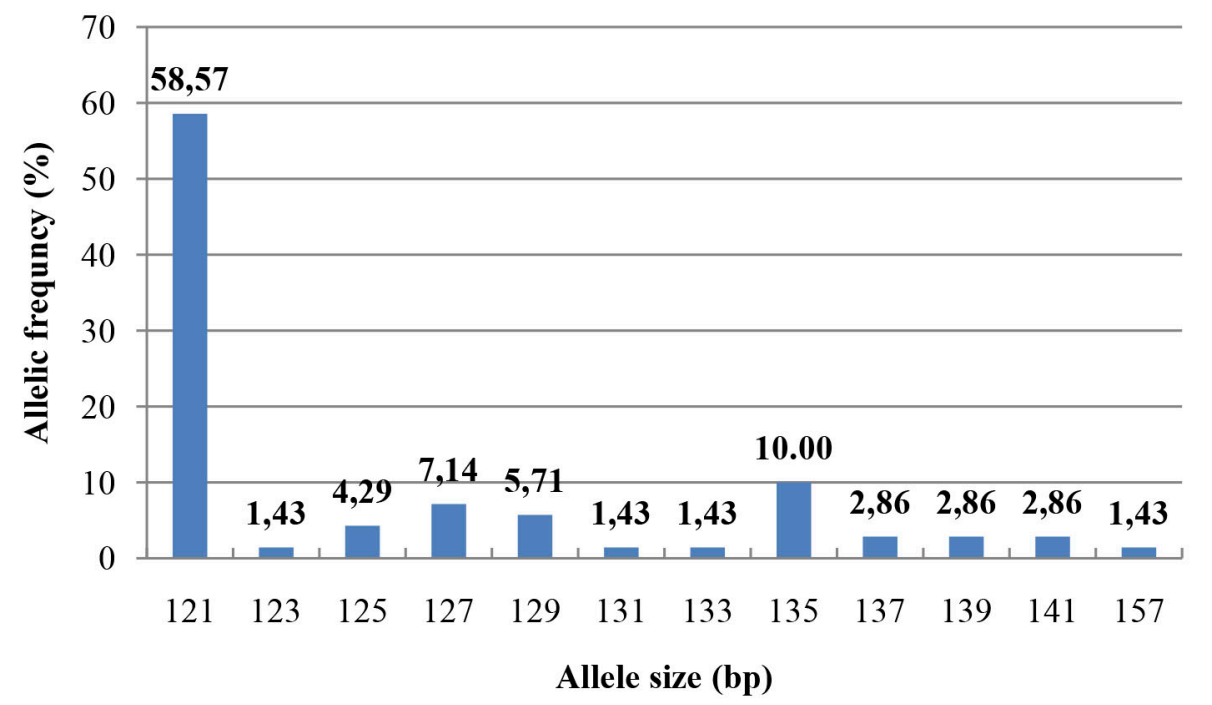

Figure 1. Allelic frequencies of Locus BM2113 in Yunnan mithun population. 

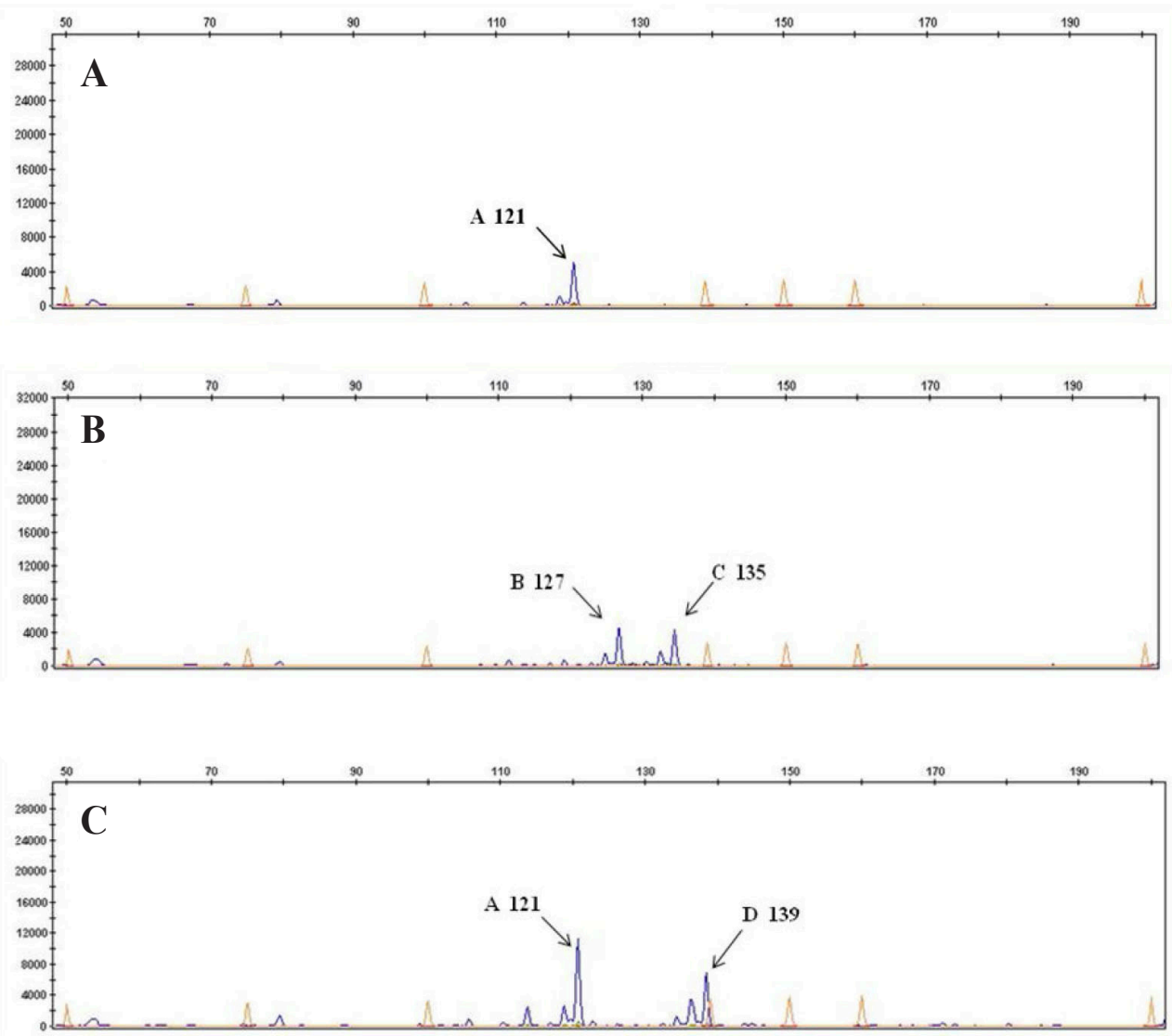

Figure 2. Four alleles of locus BM2113 are shown, A (121 bp), B (127 bp), C (135 bp) and D (139 bp), respectively. Each allele has sharp peaks and contains distinct stutter peaks (blue). A. Homozygous presentation of alleles A; B. and $\mathbf{C}$. heterozygotes with two stutter peaks.

\section{ACKNOWLEDGMENTS}

Research supported by grants from the programs from Functional Genome of Important Economic Traits in Chinese Beef Cattle (\#2013AA102505), Breeding Technology of Molecular and Cellular Engineering to High-grade Beef Cattle (\#2011AA100307-02), National Twelfth "Five Year" Science and Technology Support Project (\#2011BAD28B04-03), Technological Innovation and Training Innovative Talents Program of Yunnan Province (\#2010CI082), and National Basic Research Project of China (“973” Program, \#2007CB815704).

\section{REFERENCES}

Armstrong E, Iriarte A, Martinez AM, Feijoo M, et al. (2013). Genetic diversity analysis of the Uruguayan Creole cattle breed using microsatellites and mtDNA markers. Genet. Mol. Res. 12: 1119-1131.

Azam A, Babar ME, Firyal S, Anjum AA, et al. (2012). DNA typing of Pakistani cattle breeds Tharparkar and Red Sindhi by microsatellite markers. Mol. Biol. Rep. 39: 845-849.

Bicalho HM, Pimenta CG, Mendes IK, Pena HB, et al. (2006). Determination of ancestral proportions in synthetic bovine 
breeds using commonly employed microsatellite markers. Genet. Mol. Res. 5: 432-437.

Botstein D, White RL, Skolnick M and Davis RW (1980). Construction of a genetic linkage map in man using restriction fragment length polymorphisms. Am. J. Hum. Genet. 32: 314-331.

Gou X, Wang Y, Yang S, Deng W, et al. (2010). Genetic diversity and origin of Gayal and cattle in Yunnan revealed by mtDNA control region and SRY gene sequence variation. J. Anim. Breed. Genet. 127: 154-160.

He ZX, Qu KX, Yuan XP, San YH, et al. (2009). Appearance characteristics and major behavior of gayal (Bos frontalis) on the conservation ex situ in Pheonix mountain. J. Yunnan Agric. Univ. Nat. Sci. 24: 25-30.

Kakampuy W, Tanomtong A, Chaveerach A and Sangpakdee W (2007). New Robertsonian translocation chromosomes in captive Thai gaur (Bos gaurus readei). Pak. J. Biol. Sci. 10: 2185-2191.

Kantanen J, Olsaker I, Holm LE, Lien S, et al. (2000). Genetic diversity and population structure of 20 North European cattle breeds. J. Hered. 91: 446-457.

Karthickeyan SMK, Sivaselvam SN, Selvam R and Thangaraju P (2009). Microsatellite analysis of Kangayam cattle (Bos indicus) of Tamilnadu. Indian J. Sci. Technol. 2: 38-40.

Kim KS, Yeo JS and Choi CB (2002). Genetic diversity of north-east Asian cattle based on microsatellite data. Anim. Genet. 33: 201-204.

Lekagul B and McNeely JA (1977). Mammals of Thailand. 1st edn. Kurusapha Ladprao Press, Bangkok, Thailand.

Lekagul B and McNeely JA (1988). Mammals of Thailand. 2nd edn. Sahakarn Bhaet, Bangkok, Thailand.

Li MH and Kantanen J (2010). Genetic structure of Eurasian cattle (Bos taurus) based on microsatellites: clarification for their breed classification. Anim. Genet. 41: 150-158.

Liao XJ, Chang H, Wang DL, Song WT, et al. (2008). Genetic diversity of five native Chinese yak breeds based on microsatellite DNA markers. Biodivers. Sci. 16: 156-165.

MacHugh DE, Shriver MD, Loftus RT, Cunningham P, et al. (1997). Microsatellite DNA variation and the evolution, domestication and phylogeography of taurine and zebu cattle (Bos taurus and Bos indicus). Genetics 146: 1071-1086.

Mao Y, Chang H, Yang Z, Zhang L, et al. (2008). The analysis of genetic diversity and differentiation of six Chinese cattle populations using microsatellite markers. J. Genet. Genomics 35: 25-32.

Nguyen TT, Genini S, Menetrey F, Malek M, et al. (2005). Application of bovine microsatellite markers for genetic diversity analysis of Swiss yak (Poephagus grunniens). Anim. Genet. 36: 484-489.

Nguyen TT, Genini S, Bui LC, Voegeli P, et al. (2007). Genomic conservation of cattle microsatellite loci in wild gaur (Bos gaurus) and current genetic status of this species in Vietnam. BMC Genet. 8: 77.

Novoa MA and Usaquén W (2010). Population genetic analysis of the Brahman cattle (Bos indicus) in Colombia with microsatellite markers. J. Anim. Breed. Genet. 127: 161-168.

Qu KX, Zhu FX, Wu GS, Nie L, et al. (2006). Genetic diversity and population structure of BMY and brahman cattle revealed by six microsatellite loci. Yi Chuan 28: 285-290.

Qu KX, Nguyen SN, He ZX, Huang BZ, et al. (2012). Genetic diversity and bottleneck analysis of Yunnan mithun (Bos frontalis) using microsatellite loci. Afr. J. Biotechnol. 11: 2912-2919.

Raymond M and Rousset F (1995). An exact test for population differentiation. Evolution 49: 1280-1283.

Ritz LR, Glowatzki-Mullis ML, MacHugh DE and Gaillard C (2000). Phylogenetic analysis of the tribe Bovini using microsatellites. Anim. Genet. 31: 178-185.

Rivière-Dobigny T, Doan LP, Quang NL, Maillard JC, et al. (2009). Species identification, molecular sexing and genotyping using non-invasive approaches in two wild bovids species: Bos gaurus and Bos javanicus. Zoo. Biol. 28: 127-136.

Sunden SL, Stone RT, Bishop MD, Kappes SM, et al. (1993). A highly polymorphic bovine microsatellite locus: BM2113. Anim. Genet. 24: 69.

Tian YH, Huo JL, Li SY, Huo HL, et al. (2011). Genetic diversity of gayal by microsatellite DNA marker. J. Yunnan Agric. Univ. Nat. Sci. 26: 41-47.

Wang JH, Zan LS, Zhang GX, Wang ZG, et al. (2008). Analysis of genetic diversity on nine native yellow cattle breeds in southern China and three introduced breeds. J. Northwest A \& F Univ. Nat. Sci. 36: 1-7.

Xuebin Q, Jianlin H, Lkhagva B, Chekarova I, et al. (2005). Genetic diversity and differentiation of Mongolian and Russian yak populations. J. Anim. Breed. Genet. 122: 117-126.

Zhang GX, Wang ZG, Chen WS, Wu CX, et al. (2007a). Genetic diversity and population structure of indigenous yellow cattle breeds of China using 30 microsatellite markers. Anim. Genet. 38: 550-559.

Zhang Y, Sun D, Yu Y and Zhang Y (2007b). Genetic diversity and differentiation of Chinese domestic buffalo based on 30 microsatellite markers. Anim. Genet. 38: 569-575.

Zhang G, Chen W, Xue M, Wang Z, et al. (2008). Analysis of genetic diversity and population structure of Chinese yak breeds (Bos grunniens) using microsatellite markers. J. Genet. Genomics 35: 233-238.

Zhang Y, Vankan D, Zhang Y and Barker JS (2011). Genetic differentiation of water buffalo (Bubalus bubalis) populations in China, Nepal and south-east Asia: inferences on the region of domestication of the swamp buffalo. Anim. Genet. 42: $366-377$. 